\title{
EFFECT OF GERMINATION AND COOKING ON IRON CONTENT, PHYTIC ACID AND LECTINS OF FOUR VARIETIES OF CHILEAN BEANS (Phaseolus Vulgaris)
}

\author{
POBLETE, $T^{l}$; REBOLLEDO, $K^{1}$; BARRERA, $C^{l}$; ULLOA, $D^{l}$; VALENZUELA, $M^{l}$; VALENZUELA, $C^{l}$; \\ PAVEZ, $E^{1}$; MENDOZA, $R^{l}$; NARBONA, $C^{1}$; GONZÁLEZ, ${ }^{l}$; ESTEVEZ, $S^{2^{*}}$; ORTEGA, $R^{{ }^{1 *}}$ AND GONZÁLEZ, $C^{1^{*}}$ \\ ${ }^{I}$ Grupo de Investigación en Productos Naturales Lawen. Escuela Agrícola y Agroindustrial. Inacap Santiago Sur. Vicuña Mackenna 3864, Macul. Santiago. \\ ${ }^{2}$ Centro de Innovación Gastronómica, Inacap. Avenida Apoquindo 7282, Vitacura, Santiago.
}

\begin{abstract}
The family of Fabaceae has been fundamental into the traditional nutrition in South America, including Chile, however in this country has reduce consumption of legumes between children in school age. This investigation pursued establish the impact over nutritional and no nutritional composition of chilean beans (Phaseolus vulgaris) exposed to cook and germination. The results obtained has shown the cooked samples has decreased the contain of iron and also diminished in total minerals from ashes analysis, instead the germinated samples increased both. Total proteins determined by Kjeldahl method exhibit no change for cooked and germinated beans in relation to control without treatment, while phytic acid increased and lectins decreased with the action of cook or germination of P.vulgaris. All the analysis was supported by statistical assessment and suggest the beans germination is a good alternative to improve the variety of recipes available to prepare beans in other attractive presentations on the subject of promote the children intake.
\end{abstract}

Keywords: Beans, Lectins, Phytic acid, Germinated, Hemagglutinating.

\section{INTRODUCTION}

The Chilean bean corresponds to an annual herbaceous plant, belonging to the Fabaceae family and the genus Phaseolus, which includes five domesticated species, including $P$. vulgaris or common bean. This plant has its primary origin in Mesoamerica, being also domesticated in the Southern Andes region for at least 7000 years [1], [2]. In Chile, the predominating genetic variety is Los Andes del Sur[3] and the cultivation of legumes is located in the south-central part of the country, the BioBío region (formerly eighth region of Chile) being the one with the largest number of hectares planted, of which $40 \%$ corresponds to beans [4]. Alas, local economic constraints do not allow competing with countries such as Canada that is one of the main exporters of legumes worldwide. Globally, beans represent $15 \%$ of the arable land in the world [5], and are considered by FAO as the most important legume for direct consumption on the planet. Its high protein and dietary fibre content, as well as the presence of phenolic compounds and tocopherols with antioxidant activity, peptides, amino acids and minerals has been well described in the literature.[5]-[7]. However, it is also interesting to consider its benefits in agriculture, with its high nitrogen fixing activity, contribution of organic matter and reduction of pests in soils, as well as its low water consumption whilst obtaining calories, proteins and fats compared to other crops or animal products [4].

In addition to nutritional components, beans also have non-nutritional components. Toxic substances that reduce nutrient utilization and can be classified into two large groups: thermo-stable and thermo-labile. Phytic acid stands out in the former while lectins do so in the latter[8]. Phytic acid forms especially stable complexes with minerals such as zinc, calcium and iron, preventing its absorption in the intestinal tract, resulting in gastrointestinal symptoms such as nausea and diarrhoea. Lectins, also called phytohematoagglutinins, are glycoproteins that have high selectivity towards carbohydrates and can agglutinate red blood cells. Its adverse effects described are related to a reduction in growth and weight loss in laboratory animals, associated with the reduction in the absorption of digestion products in the small intestine [6], [9], [10]. On the other hand, these non-nutritional components have shown anti-tumour and anti-proliferative effects in colorectal cancer cell lines[11]. It has also been observed that the consumption of these anti-nutrients reduces blood sugar levels, which is highly desirable for diseases such as diabetes and hyperlipidemia[12]. Despite this background, the consumption of legumes in Chile has decreased by around $28 \%$ in the past decade[13]. Multiple factors influence this decrease in consumption, mostly socio-cultural issues, associating this food with the working class, as well as the time taken for their preparations[14], [15].
Considering this background, our interest focuses on determining the content of these components and assessing the effect of germination and cooking on this composition for four varieties of Chilean beans ( $P$. vulgaris). In addition, to contribute to the diversification of preparations for this food in a recipe book created by the Inacap Center for Gastronomic Innovation, encouraging the consumption of beans.

\section{MATERIAL AND METHODS}

\subsection{Plant materials and Reagents}

The plant material used corresponds to 4 varieties of Chilean bean seeds (Phaseolus vulgaris): found, black, young and white. These were bought in the Central Market of Santiago. Samples are preserved for later analysis.

Lectin (from Phaseolus vulgaris), phytic acid sodium salt hydrate, 3-(2pyridyl)-5,6-diphenyl-1,2,4-triazine-4',4'-disulphonic acid sodium salt (ferrozine) $\geq 97.0 \%$ and Iron standard solution $1 \mathrm{mg} / \mathrm{mL}$ Fe were purchased from Sigma-Aldrich and used without prior purification. Defibrinated rabbit blood was purchased at the Public Health Institute of Chile, ISP. Kjeldahl tablets, sulfuric acid $95-97 \%$ p.a, boric acid p.a, hydrochloric acid 0.1 and $1 \mathrm{M}$ Titrisol®, $2 \mathrm{M}$ Titripur ${ }^{\circledR}$, L-ascorbic acid p.a, ammonium acetate p.a, sodium chloride p.a, iron (III) chloride hexahydrate p.a, 5-sulfosalicylic acid dihydrate for synthesis were purchased from Merck and used without prior purification.

The spectrophotometric measurements were performed on a Rayleight UV-Vis spectrophotometer, China. Nitrogen determination was performed on a SpeedDigester K-425 Buchi digester and distillation was performed on an automatic K-350 Buchi distiller. Hemagglutination readings were performed on Optimus optical microscopes.

\subsection{Treatment}

The four varieties of beans were subjected to two treatments: germination and cooking. For the germination healthy specimens were selected, washed with $70 \%$ ethanol solution and rinsed with distilled water, then subjected to germination in Petri dishes with wet paper in an incubator at $22{ }^{\circ} \mathrm{C}$ for 5 days. Once germinated, the beans were dried at $105^{\circ} \mathrm{C}$ for 2 hours, crushed to fine powder and stored under vacuum at $-20{ }^{\circ} \mathrm{C}$ until analysis.

Healthy specimens were selected for cooking and a mass:solvent ratio of 1:10 with deionized water was used. 25 grams of each variety were deposited in a beaker to which $250 \mathrm{~mL}$ of deionized water was added. 
This system took two autoclave cycles of 15 minutes each. After this the content was filtered and the beans were dried at $105^{\circ} \mathrm{C}$ for two hours, crushed to fine powder and stored under vacuum at $-20{ }^{\circ} \mathrm{C}$ until analysis.

As raw control, raw beans were used, which were dried at $105{ }^{\circ} \mathrm{C}$ for two hours, crushed to fine powder and stored under vacuum at $-20{ }^{\circ} \mathrm{C}$ until analysis.

\subsection{Gravimetric Analysis}

The moisture content was determined according to the drying method in an oven with air circulation[16], with few modifications. Approximately 2 grams of a sample are weighed in a porcelain capsule and placed in an oven with air circulation for 2 hours at $105^{\circ} \mathrm{C}$. They are cooled and kept in a desiccator until their final mass is registered. The moisture content $(\% \mathrm{w} / \mathrm{w})$ is calculated according to the following formula and is reported as the average of three measurements.

$$
\% \text { Moisture }=\frac{\left(\begin{array}{c}
\text { wof wet sample } \\
+ \text { pan }
\end{array}\right)-\left(\begin{array}{c}
\text { wof dried sample } \\
+ \text { pan }
\end{array}\right)}{(\text { wof } \text { wet sample }+ \text { pan })-(\text { w of pan })} \times 100
$$

The ash content is determined according to the muffle heating method[16], with few modifications. Approximately 2 grams of sample are weighed in a porcelain crucible and they are placed in a muffle oven for 24 hours at $550{ }^{\circ} \mathrm{C}$. They are cooled and preserved in desiccator until their final mass is registered. The percentage of ashes ( $\% \mathrm{w} / \mathrm{w})$ is calculated according to the following formula and is reported as the average of three measurements.

$$
\% \text { Ash }=\frac{(\text { wof ash })}{(\text { wof wet sample })} \times 100
$$

\subsection{Protein Nitrogen Determination}

The nitrogen content of the beans studied was determined by the Kjeldahl method. Approximately $1 \mathrm{~g}$ of dried beans are weighed and transferred to a digestion tube. A catalyst tablet and $10.0 \mathrm{~mL}$ of concentrated sulfuric acid are added. Blanks are prepared by adding a catalyst tablet and $10 \mathrm{~mL}$ of concentrated sulfuric acid to the digestion tube. The tubes are mounted in the digester rack and this is taken to the digestion block, connecting the vapor extraction system. Digestion is maintained for two hours, confirming that these must be clear and do not have carbonized material. The tubes are cooled and diluted with $50 \mathrm{~mL}$ of deionized water, stirring until completely dissolved. Each tube is then taken to the distillation system and a flask with boric acid (4\% w/v) and two drops of the red methyl indicator and one drop of methylene blue are placed to collect the distillate. Distillation is carried out for 10 minutes for each tube. Finally, the distillate titration is performed using standardized $0.1 \mathrm{M} \mathrm{HCl}$ until the indicator changes colour from green to pink. The consumed volume of standard $\mathrm{HCl}$ is recorded and the calculations are performed according to the following formula.

$$
\% N=\frac{(m L H C l \text { std }-m L \text { blank }) \times M H C l \text { std } x 1,4007}{g \text { sample }}
$$

$$
\% \text { Protein }=\% N x \text { Protein Factor }
$$

The protein factor used is 6.25 . The measurements were made in triplicate.

\subsection{Iron Determination}

The iron content was determined from the ashes of the four varieties of beans in its two treatments and in the control by the method of Ferrozine[16], with slight modifications. Calibration standards were prepared containing 0, 2, 4, 6, 8 and $10 \mu \mathrm{g} \mathrm{Fe} / \mathrm{mL}$ from a standard solution of $10 \mu \mathrm{g} \mathrm{Fe} / \mathrm{mL}$. Samples were prepared by dissolving approximately $0.5 \mathrm{~g}$ of ashes in a small portion of $1 \mathrm{M}$ $\mathrm{HCl}$ and then $0.1 \mathrm{M} \mathrm{HCl}$ was added to $50 \mathrm{~mL}$ in a volumetric flask. For measurements, $0.500 \mathrm{~mL}$ of standards or samples are taken in $10 \mathrm{~mL}$ test tubes. $1.250 \mathrm{~mL}$ of ascorbic acid $(0.02 \%$, freshly prepared in $2 \mathrm{M} \mathrm{HCl})$ is added and placed on a vortex mixer and then allowed to stand for 10 minutes. $2.000 \mathrm{~mL}$ of ammonium acetate $(30 \% \mathrm{w} / \mathrm{v})$ is added and stirred on a vortex mixer. $1.250 \mathrm{~mL}$ of Ferrozine ( $1 \mathrm{mM}$ in water) are added, stirred on a vortex mixer and allowed to stand in the dark for 15 minutes. Finally, the absorbance at $562 \mathrm{~nm}$ is read against a blank containing $0.500 \mathrm{~mL}$ of deionized water instead the sample. The results are listed as $\mu \mathrm{g} \mathrm{Fe} / \mathrm{g}$ dry bean and reporting the average of three determinations.

\subsection{Phytic acid determination}

The phytic acid (PA) content was determined by the colorimetric method with Wade reagent[17], with minor modifications. The extraction was carried out on $0.5 \mathrm{~g}$ of beans that were mixed with $10 \mathrm{~mL}$ of $2.4 \% \mathrm{HCl}$ in a centrifuge tube that was subjected to orbital agitation at $220 \mathrm{rpm}$ for 16 hours and centrifuged at 1000 $g$ for 20 minutes at $10^{\circ} \mathrm{C}$. Crude extracts are collected for PA analysis. The crude extracts are transferred to test tubes containing $1 \mathrm{~g}$ of $\mathrm{NaCl}$, stirred orbitally at $350 \mathrm{rpm}$ for 20 minutes and allowed to stand at $-20{ }^{\circ} \mathrm{C}$ for 20 minutes. This mixture is centrifuged at $1000 \mathrm{~g}$ for 20 minutes at $10{ }^{\circ} \mathrm{C}$ and $1.000 \mathrm{~mL}$ of the supernatant is diluted to $10 \mathrm{~mL}$ with deionized water. For quantification, 3.000 $\mathrm{mL}$ of the supernatant or standards are mixed with $1.000 \mathrm{~mL}$ of the Wade reagent $\left(0.03 \% \mathrm{FeCl}_{3} \times 6 \mathrm{H}_{2} \mathrm{O}\right.$ and $0.3 \%$ Sulfosalicylic acid), mixed vigorously in a vortex stirrer and centrifuged at $1000 \mathrm{~g}$ for 10 minutes at $10{ }^{\circ} \mathrm{C}$ The absorbance at 500 $\mathrm{nm}$ is recorded on a spectrophotometer and the results are expressed as $\mathrm{mg} \mathrm{PA} / \mathrm{g}$ bean. All trials were done in sextuplicate.

\subsection{Lectin determination}

The Lectin determination was performed by the red blood cell agglutination method[18]. First, hematoagglutinins are extracted on 1 gram of dried beans using $10 \mathrm{~mL}$ of $0.9 \% \mathrm{NaCl}$ in a centrifuge tube. The mixture is stirred for one minute in a vortex mixer and then left in a shaker for 1 hour. The suspension is allowed to stand in the refrigerator at $4{ }^{\circ} \mathrm{C}$ overnight and then centrifuged at $14190 \mathrm{~g}$ for 10 minutes at $4{ }^{\circ} \mathrm{C}$. After filtering, the supernatant is successively diluted in 1.5 mL Eppendorf tubes. A dilution range of 0 in tube 1 to 1: 8192 (extract: saline, v/v) in tube 14 and a final volume of $0.5 \mathrm{~mL}$ was used. $0.05 \mathrm{~mL}$ of $2 \%$ rabbit red blood cell solution was added to each tube, stirred and allowed to stand for 2 hours. Hemagglutinin activity (HA) was determined microscopically by taking a drop of each tube, transferring it to an object holder and covering it with a coverslip. At least five cells added together are considered positive evidence of agglutination. A blank was prepared containing $0.05 \mathrm{~mL}$ of saline and $0.05 \mathrm{~mL}$ of red blood cell solution. A positive control was also prepared by mixing $0.05 \mathrm{~mL}$ of lectin solution $(1: 1, \mathrm{~m} / \mathrm{v}$ in phosphate buffered saline, $\mathrm{pH}=6.8)$. The lowest dilution of the extracts produced by a positive agglutination is defined as that which contains a Hemagglutinin Unit (HU). The specific activity of each bean (HU/mg bean) is calculated according to the following formula.

$$
\frac{H U}{m g}=\frac{D_{a} \times D_{b} \times S}{V}
$$

Where,

$D_{a}=$ Dilution factor in tube 1 (1 unless the solution is diluted)

$D_{b}=$ Dilution factor in the tube showing a $\mathrm{HU}$

$S=\mathrm{mL}$ original extract $/ \mathrm{mg}$ of bean

$V=\mathrm{mL}$ of the extract in tube 1

\subsection{Statistical Analysis}

All determinations were made at least in triplicate and the results are presented as average \pm standard deviation. Two-factor ANOVA was performed and Tukey test considering significant differences for $p$ values less than 0.05. All analyses were done with Microsoft Excel 2017 (Microsoft Office 2017) and GraphPad Prism version 6.012012 (GraphPad Software Inc 2012).

\section{RESULTS AND DISCUSSION}

\subsection{Gravimetric analysis}

The results of moisture and ash content are shown in Table 1. The Black bean has the highest percentage of moisture with $9.19 \%$, while the Miss bean shows the lowest of the raw varieties with $6.58 \%$. Although the Black bean shows the highest percentage of moisture in the germination treatment, it is the Miss variety that holds the highest amount of water in the process, increasing its content almost 8 times. Our results are correlated with those obtained for common bean flour, with values that vary between 6.4 and $8.9 \%$ humidity[19]. Figure 1 shows the effect of the treatment on the moisture and ash content. It is observed that cooking increases the water content at least 7 times, again showing that Miss bean has the biggest increase. The statistical analysis shows an extremely significant influence of the treatment, accounting for $99.81 \%$ of the total variance. 
Table 1. Effect of the treatment on the \% of moisture and ashes for the four varieties of raw, sprouted and cooked beans. The results correspond to the average of three replicates and their standard deviation.

\begin{tabular}{|c|c|c|c|}
\hline \multirow{2}{*}{ Type } & \multicolumn{3}{|c|}{ \% Moisture } \\
\cline { 2 - 4 } & Raw & Germinated & Cooked \\
\hline \multirow{2}{*}{ Black } & $9.19 \pm 0.06$ & $54.26 \pm 0.35$ & $70.40 \pm 0.04$ \\
\hline Found & $8.72 \pm 0.12$ & $50.39 \pm 0.74$ & $70.41 \pm 0.65$ \\
\hline White & $8.33 \pm 0.09$ & $51.57 \pm 0.82$ & $71.03 \pm 1.23$ \\
\hline Miss & $6.58 \pm 0.06$ & $51.71 \pm 0.24$ & $71.24 \pm 1.88$ \\
\hline
\end{tabular}

\begin{tabular}{|c|c|c|}
\hline \multicolumn{3}{|c|}{$\%$ Ash } \\
\hline Raw & Germinated & Cooked \\
\hline $4.31 \pm 0.08$ & $4.45 \pm 0.06$ & $2.47 \pm 0.04$ \\
\hline $3.90 \pm 0.16$ & $4.39 \pm 0.04$ & $2.30 \pm 0.15$ \\
\hline $4.14 \pm 0.06$ & $4.60 \pm 0.14$ & $2.50 \pm 0.05$ \\
\hline $3.95 \pm 0.34$ & $4.25 \pm 0.06$ & $2.73 \pm 0.34$ \\
\hline
\end{tabular}

The ash content is an important parameter in food because it represents the content of available minerals. Our results show that the Black bean is the variety with the highest amount of ashes $(4.31 \%)$ for raw beans, while the White bean is the variety that generates the highest amount of ashes germinated with $4.60 \%$ and finally the cooked Miss bean with $2.73 \%$. A review on the chemical composition of common beans shows ash values for raw beans that are similar in magnitude and error as those obtained in our study[6]. Although the differences observed between varieties are not significant in the ash content, the treatment shows significant influence of the germination on the raw bean, increasing in ranges that go from 3 to $11 \%$, being the Found bean the one that shows the bigger increase These results are shown in Figure 1.

\section{Moisture content}

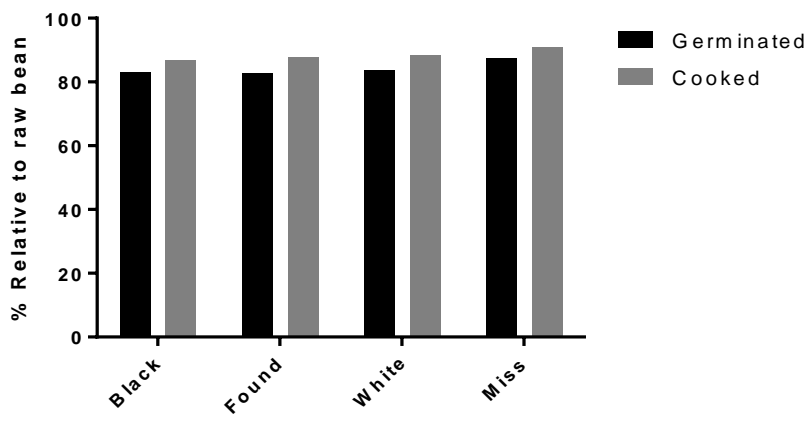

Ash content

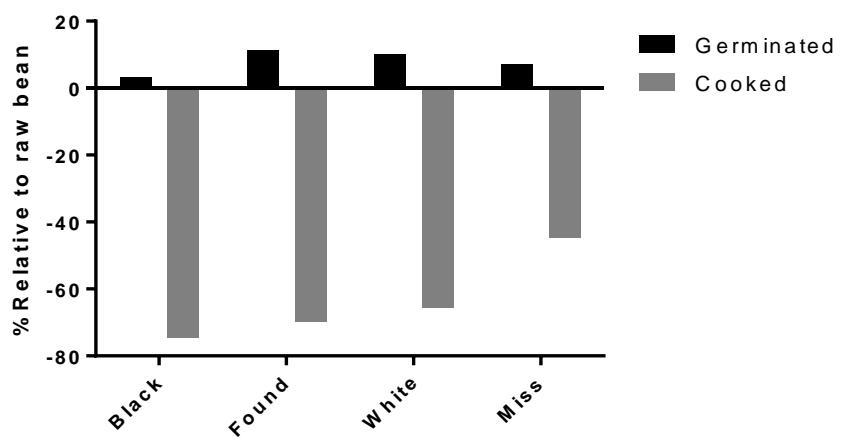

Figure 1. Percentage of gain or loss in the moisture and ash content of the different treatments. The values were calculated from the content of the raw beans.

Interestingly, the cooking treatment significantly decreases the amount of ashes, which would potentially reduce the availability of minerals for the food intake. The greatest effect is observed in the Black bean, with a decrease of $74 \%$ while the Miss bean presents the smallest variation with a decrease of $44 \%$.

\subsection{Nitrogen content}

The nitrogen content results are shown in Table 2 . The $\% \mathrm{~N}$ varies significantly between the raw bean varieties, from $3.29 \%$ in the White bean to $3.79 \%$ in the
Black bean. A similar behaviour is observed for cooked bean varieties, with values ranging from $3.36 \%$ in beans found to $4.39 \%$ in black beans. For germinated beans, there are no significant variations between them, the Black bean being the variety that contributes more nitrogen with $3.92 \%$. All results are in agreement with those reported for common bean [5], [6], [19], [20]. Although it is not possible to establish a significant effect of the treatment on the nitrogen content, germination causes increases with respect to the raw bean, which vary between 1.8 and $7.2 \%$, finding the greatest variation in the bean found, as can be seen in Figure 2. The cooking shows a more variable behaviour in terms of the change in the nitrogen content, with increases ranging from $0.3 \%$ and $13.7 \%$, where the Black bean shows the greatest increase, however the Miss bean results in a $1.6 \%$ decrease, which could be explained by the dissolution of soluble proteins [19].

Table 2. Effect of the treatment on the nitrogen content for the four varieties studied. The results correspond to the analysis of triplicate samples and are presented as the average and its standard deviation.

\begin{tabular}{|c|c|c|c|}
\hline \multirow{2}{*}{ Type } & \multicolumn{3}{|c|}{ \% N } \\
\cline { 2 - 4 } & Raw & Germinated & Cooked \\
\hline Black & $3.79 \pm 0.06$ & $3.92 \pm 0.16$ & $4.39 \pm 0.28$ \\
\hline Found & $3.35 \pm 0.01$ & $3.61 \pm 0.21$ & $3.36 \pm 0.01$ \\
\hline White & $3.29 \pm 0.04$ & $3.42 \pm 0.08$ & $3.45 \pm 0.17$ \\
\hline Miss & $3.75 \pm 0.13$ & $3.82 \pm 0.21$ & $3.69 \pm 0.00$ \\
\hline
\end{tabular}

Nitrogen content

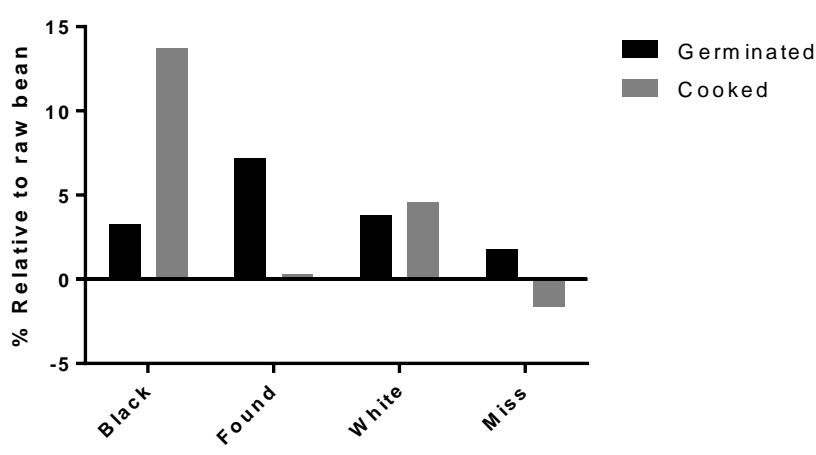

Protein content

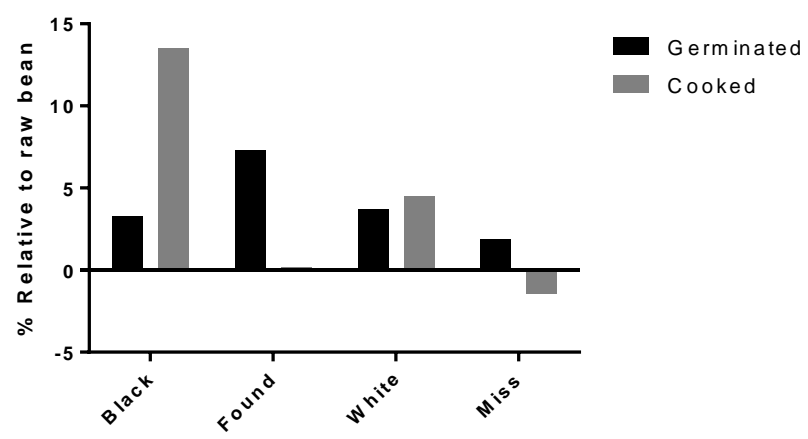

Figure 2. Percentage of gain or loss in the nitrogen and protein content of the different treatments. The values were calculated from the content of the raw beans.

Protein content is an important parameter from the point of view of food. A characteristic of beans is its high protein intake. The results of the analysed samples can be seen in Table 3. A similar trend to nitrogen content is observed for protein content, the bean type being the most influential factor in the variations found. The Black bean is the variety that makes the greatest contribution of nitrogen with $23.7 \%, 24.51 \%$ and $26.96 \%$ for the raw, germinated and cooked treatment, respectively. The data obtained are comparable to those 
reported for $P$. vulgaris [6], [7], [19] and show the high protein contribution of the Chilean beans analysed.

Table 3. Effect of the treatment on the protein content for the four varieties studied. The results correspond to the analysis of triplicate samples and are presented as the average and its standard deviation.

\begin{tabular}{|c|c|c|c|}
\hline \multirow{2}{*}{ Tipo } & \multicolumn{3}{|c|}{ \% Protein } \\
\cline { 2 - 4 } & Raw & Germinated & Cooked \\
\hline Black & $23.70 \pm 0.38$ & $24.51 \pm 0.95$ & $27.39 \pm 1.75$ \\
\hline Found & $20.93 \pm 0.04$ & $22.58 \pm 1.35$ & $20.98 \pm 0.04$ \\
\hline White & $20.59 \pm 0.25$ & $21.39 \pm 0.53$ & $21.56 \pm 1.05$ \\
\hline Miss & $23.40 \pm 0.85$ & $23.86 \pm 1.32$ & $23.08 \pm 0.01$ \\
\hline
\end{tabular}

\subsection{Iron content}

Iron is an important micronutrient for human metabolism and its presence in the bean makes this food an excellent mineral intake in the diet. The effect of the treatments on the iron content can be seen in Table 4. The results show a significant increase of two to five times for the iron content in the four germinated bean varieties compared to the raw bean, which can due to the hydrolysis of iron compounds due to high water retention in germination.

Table 4. Effect of treatment on iron content for the four varieties of beans analysed. The results correspond to the average and its standard deviation for three replicas. $\mathrm{ND}=$ not detectable.

\begin{tabular}{|l|c|c|c|}
\hline \multirow{2}{*}{ Type } & \multicolumn{3}{|c|}{ Iron content $(\boldsymbol{\mu g}$ Fe/g bean) } \\
\cline { 2 - 4 } & Raw & Germinated & Cooked \\
\hline Black & $17.7 \pm 0.5$ & $30.0 \pm 4.4$ & ND \\
\hline Found & $12.8 \pm 0.7$ & $41.1 \pm 1.4$ & ND \\
\hline White & $15.0 \pm 0.40$ & $74.2 \pm 2.9$ & ND \\
\hline Miss & $16.8 \pm 1.3$ & $47.1 \pm 0.5$ & ND \\
\hline
\end{tabular}

The Black bean shows the highest iron value in raw beans with $16.8 \mu \mathrm{g} \mathrm{Fe} / \mathrm{g}$ bean while the White bean shows the highest value for germinated beans with $74.2 \mu \mathrm{g} \mathrm{Fe} / \mathrm{g}$ bean. These values are similar to those reported for Chilean beans in their iron content [21]. In addition, the White bean shows the highest increase $(79.8 \%)$ in iron content, while the Black bean the lowest $(41.0 \%)$ for germination. Interestingly cooked beans in all its varieties have iron contents below the limits of detection of the method, suggesting the different forms of iron are indeed present in the cooking water, thus making it gastronomically relevant.

The statistical analysis shows an extremely significant influence of both factors, type of bean and treatment, as well as their interaction, so it is possible to establish that the germinated bean significantly increases its iron content, while the cooked bean loses this mineral by dissolution, which is in agreement with the results obtained for moisture and ash content of the beans analysed in this study.

\subsection{Phytic acid content}

The phytic acid content varies significantly between the four varieties studied, both in raw, sprouted and cooked beans, as can be seen in Table 5. For raw beans, values vary between 2.03 and $3.06 \mathrm{mg} / \mathrm{g}$, the white bean being the one with the highest contribution of phytic acid. For sprouted beans, the values are distributed between 2.96 and $4.86 \mathrm{mg} / \mathrm{g}$ with the Black bean being the variety that provides the most phytic acid. Finally, for the cooking treatment, values between 3.04 and $4.51 \mathrm{mg} / \mathrm{g}$ are observed, the Black bean again being the one with the highest phytic acid content. These values are comparable to those obtained in a study with 50 varieties of common bean, with an average value of $3.102 \mathrm{mg} / \mathrm{g}$ of phytic acid [10].
The analysis of variance shows that the type of beans, the treatment and their interaction have significant effects on the phytic acid content. All varieties show an increase in the content of this component with the germination treatment, with the White bean being the one that shows the smallest increase. However, although a similar trend is observed in cooked beans, the White variety shows a slight decrease due to treatment. Figure 3 shows that for the Black bean, although there is an increase of 53.1 and $49.5 \%$ in the PA content for the germinated and cooked bean respectively, these values do not differ statistically, therefore a discrepancy between germination and cooking is not observed. A similar behaviour is shown in the Miss bean, allowing to establish that the treatment affects the content of PA, but in the same way. A study with common beans $(P$. vulgaris) from Canada[18] shows phytic acid contents that are almost four times greater than those obtained for our varieties, which can be explained by genetic, geographical, soil, climatic and other conditions well described in the literature [3], [10], [18], [22]-[27].

Table 5. Phytic Acid Content in the four varieties studied by two treatments The results correspond to the analysis of six-fold samples and are presented as the average and its standard deviation.

\begin{tabular}{|c|c|c|c|}
\hline \multirow{2}{*}{ Type } & \multicolumn{3}{|c|}{ Phytic acid content (mg PA/g bean) } \\
\cline { 2 - 4 } & Raw & Germinated & Cooked \\
\hline Black & $2.28 \pm 0.2$ & $4.86 \pm 0.05$ & $4.51 \pm 0.12$ \\
\hline Found & $2.03 \pm 0.14$ & $3.58 \pm 0.10$ & $4.42 \pm 0.27$ \\
\hline White & $3.06 \pm 0.22$ & $3.60 \pm 0.29$ & $3.04 \pm 0.18$ \\
\hline Miss & $2.11 \pm 0.08$ & $2.96 \pm 0.28$ & $3.40 \pm 0.29$ \\
\hline
\end{tabular}

Phytic acid content

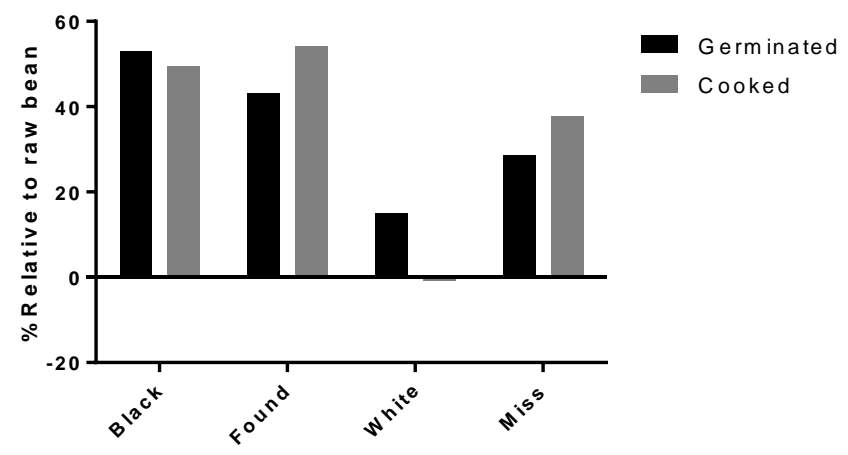

Figure 3. Percentage of gain or loss in the phytic acid content of the different treatments. The values were calculated from the content of the raw beans

\subsection{Lectin content}

The results of the hemagglutinating activity analysis of the four varieties of raw, sprouted and cooked beans are shown in Table 6 and in Figure 4. Among the raw beans, the black variety shows the highest hemagglutinating activity, with $6.29 \mathrm{HU} / \mathrm{mg}$ while the white bean shows the lowest activity with 6.20 $\mathrm{HU} / \mathrm{mg}$. A similar behaviour is observed among the germinated beans, the Black and White beans being the ones that show the highest and lowest lectin content, respectively. Statistical analysis shows that the treatment, the bean variety and its interaction significantly affect the content of lectins, reducing to undetectable amounts of lectins in cooking. These results are consistent with those shown by other studies where cooking and germination treatment significantly reduce the amount of lectins [18], [24], [28]. However, our results show values that are fourteen-fold lower compared to those of Canadian beans, a trend similar to that observed with phytic acid. The low levels of these components in the varieties analysed could even have beneficial effects depending on the extensive biological activity reported against microorganisms, antitumor, immunomodulatory, blood lipid reduction, among others [11], [24], [29]-[31]. 
Table 6. Effect of germination and cooking on the haemagglutinating activity in the four varieties of beans analysed. The results are presented as the average and the standard deviation of 6 replicates. ND $=$ Not Detectable.

\begin{tabular}{|c|c|c|c|}
\hline \multirow{2}{*}{ Type } & \multicolumn{3}{|c|}{ Lectin content (HU/mg bean) } \\
\cline { 2 - 4 } & Raw & Germinated & Cooked \\
\hline \multirow{2}{*}{ Black } & $6.29 \pm 0.10$ & $5.96 \pm 0.13$ & ND \\
\hline Found & $6.21 \pm 0.04$ & $3.17 \pm 0.06$ & ND \\
\hline White & $6.20 \pm 0.17$ & $3.06 \pm 0.21$ & ND \\
\hline Miss & $6.24 \pm 0.24$ & $3.07 \pm 0.01$ & ND \\
\hline
\end{tabular}
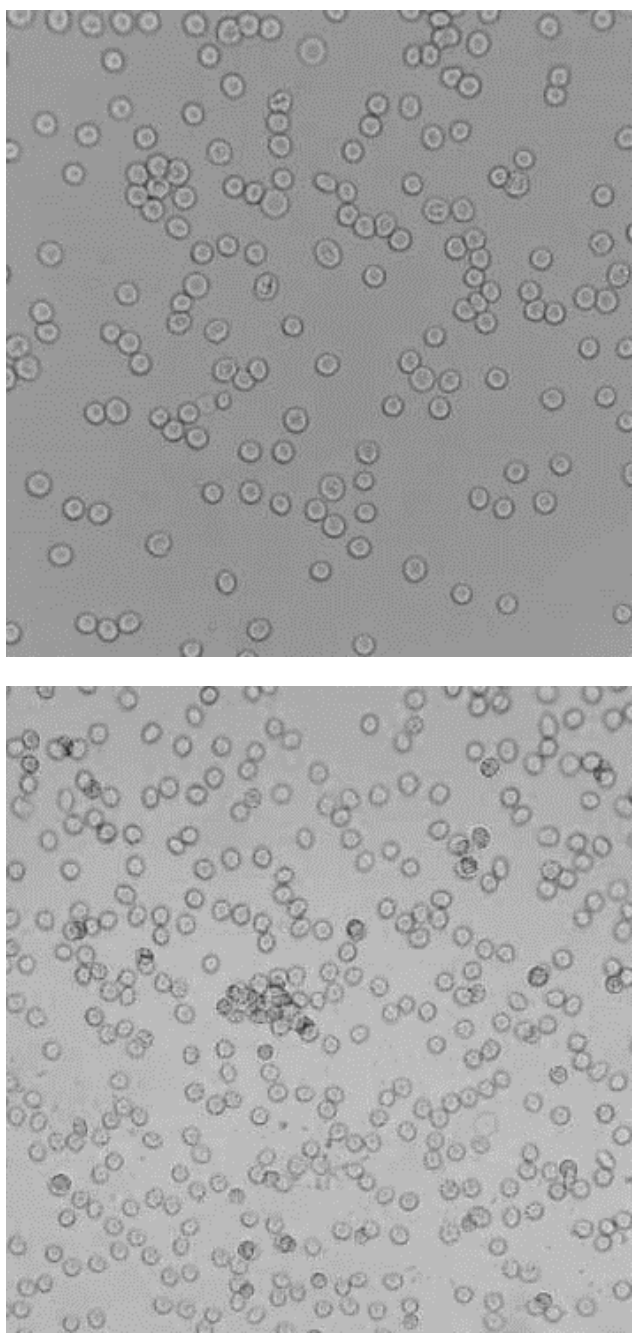

Figure 4. Photographs of the agglutination. Negative control (left) and positive agglutination for Miss Raw (right). The increase is 400x.

\section{CONCLUSIONS}

Considering the food importance of beans, as well as the systematic reduction of its consumption in Chile, the effect of germination and cooking on the content of phytic acid and lectins in four varieties of Chilean beans was studied for the first time, in order to find new gastronomic applications possibly promoting its consumption in the population.

Our results show that the mineral content available for intake significantly decreases during cooking, while germination causes an increase in these micronutrients, particularly with iron. Likewise, it is possible to establish that the protein content of the bean is not significantly affected by the treatments.
The analysis of non-nutritional components makes it possible to establish that the treatment significantly influences the content of phytic acid, however this is significantly lower than that reported for Canadian beans, highly consumed in Chile. On the other hand, the lectin content of Chilean beans shows a similar trend, being 14 times lower than that of Canadian beans, allowing to establish that the antinutritional content of Chilean beans is significantly lower than that of imported beans.

This background allows us to conclude that the germination of Chilean beans is presented as an important nutritional alternative for flour production, considering the heat treatment to which they are subsequently subjected Likewise, cooking is presented as a favourable alternative to the reduction of these nutritional and antinutritional components, so cooking water should also be used in gastronomic applications.

Finally, the low content of non-nutritional compounds presents in the varieties studied could have positive impacts on the overall nourishment and health of the Chilean population.

\section{ACKNOWLEDGEMENTS}

To my family and students who work with us. To Project PI8STSUTCIDP03 from Vicerrectoria de Investigación y Postgrados, Inacap. And finally, to Centro de Innovación Gastronómica, Inacap.

\section{REFERENCES}

1. V. M. Hernández-López and M.-P. Ma. Luisa P. Vargas-Vázquez, José S. Muruaga-Martínez, Sanjuana, Hernández-Delgado, Netzahualcóyotl, "Origen, domesticación y diversificación del frijol comun. Avances y perspectivas," Rev. Fitotec. Mex., vol. 36, no. 2, pp. 95-104, 2013.

2. B. S. Gaut, "The complex domestication history of the common bean," Nat. Genet., vol. 46, no. 7, pp. 663-664, 2014.

3. V. Viviana Becerra, C. Mario Paredes, M. Carmen Rojo, L. M. Díaz, and M. W. Blair, "Microsatellite marker characterization of Chilean common bean (Phaseolus vulgaris L.) germplasm," Crop Sci., vol. 50, no. 5, pp. 1932-1941, 2010.

4. C. Baginsky G and L. Ramos C., "Situación de las legumbres en Chile: Una mirada agronómica," Rev. Chil. Nutr., vol. 45, pp. 21-31, 2018.

5. S. M. F. Bessada, J. C. M. Barreira, and M. B. P. P. Oliveira, "Trends in Food Science \& Technology Pulses and food security: Dietary protein, digestibility , bioactive and functional properties," Trends Food Sci. Technol., vol. 93, no. 228, pp. 53-68, 2019.

6. F. G. B. Los, A. A. F. Zielinski, J. P. Wojeicchowski, A. Nogueira, and I. M. Demiate, "Beans (Phaseolus vulgaris L.): whole seeds with complex chemical composition," Curr. Opin. Food Sci., vol. 19, pp. 63-71, 2018.

7. T. G. Porch et al., "Nutritional composition and cooking characteristics of tepary bean (Phaseolus acutifolius Gray) in comparison with common bean (Phaseolus vulgaris L.)," Genet. Resour. Crop Evol., vol. 64, no. 5, pp. 935953, 2017.

8. A. Thakur, V. Sharma, and A. Thakur, "An overview of anti-nutritional factors in food," Int. J. Chem. Stud., vol. 7, no. 1, pp. 2472-2479, 2019.

9. N. Nciri, T. Shin, and N. Cho, "Public health hazards associated with naturally occurring toxins in legume seeds - Rapid detection and characterization of a lectin from a korean cultivated kidney bean (Phaseolus vulgaris L.)," Asian J. Pharm. Clin. Res., vol. 11, no. Special Issue 3, pp. 76-79, 2018.

10. R. Shang et al., "The Diversity of Four Anti-nutritional Factors in Common Bean," Hortic. Plant J., vol. 2, no. 2, pp. 97-104, 2016

11. J. Zhang, J. Shi, S. Ilic, S. Jun Xue, and Y. Kakuda, "Biological properties and characterization of lectin from red kidney bean (Phaseolus Vulgaris)," Food Rev. Int., vol. 25, no. 1, pp. 12-27, 2009.

12. L. U. Thompson, "Potential health benefits and problems associated with antinutrients in foods," Food Res. Int., vol. 26, no. 2, pp. 131-149, 1993.

13. A. Pinheiro, C. Ivanovic, and L. Rodríguez, "Consumo de legumbres en Chile. perspectivas y desafíos," Rev. Chil. Nutr., vol. 45, pp. 14-20, 2018.

14. M. J. Barros Cruz, "El poroto como metáfora de la nación, los sujetos populares y la revolución en 'Rotología del Poroto' de Pablo de Rokha," Rev. Chil. Lit., no. 90, pp. 55-78, 2015.

15. I. M. Aguilera Bornard, "Historia e identidad: elementos para pensar el consumo de porotos en Chile," Interciencia, vol. 43, no. May, pp. 379-384, 2018.

16. S. Suzanne Neilsen, Food Analysis Laboratory Manual, Third Edit. Springer, 2017.

17. Y. Gao et al., "A modified colorimetric method for phytic acid analysis in soybean," Crop Sci., vol. 47, no. 5, pp. 1797-1803, 2007. 
18. L. Shi, S. D. Arntfield, and M. Nickerson, "Changes in levels of phytic acid, lectins and oxalates during soaking and cooking of Canadian pulses," Food Res. Int., vol. 107, no. March, pp. 660-668, 2018.

19. H. M. Sánchez-Arteaga, J. E. Urías-Silvas, H. Espinosa-Andrews, and E. García-Márquez, "Effect of chemical composition and thermal properties on the cooking quality of common beans (Phaseolus vulgaris)," CYTA - J. Food, vol. 13, no. 3, pp. 385-391, 2015.

20. B. Venkidasamy, D. Selvaraj, A. S. Nile, S. Ramalingam, G. Kai, and S. H. Nile, "Indian pulses: A review on nutritional, functional and biochemical properties with future perspectives," Trends Food Sci. Technol., vol. 88, no. March, pp. 228-242, 2019.

21. M. Olivares, F. Pizarro, S. De Pablo, M. Araya, and R. Uauy, "Iron, Zinc, and Copper: Contents in Common Chilean Foods and Daily Intakes in Santiago, Chile," Nutrition, vol. 20, no. 2, pp. 205-212, 2004.

22. V. Kumar, A. Rani, S. Rajpal, G. Srivastava, A. Ramesh, and O. P. Joshi, "Phytic acid in Indian soybean: Genotypic variability and influence of growing location," J. Sci. Food Agric., vol. 85, no. 9, pp. 1523-1526, 2005.

23. P. Y. Lin and H. M. Lai, "Bioactive compounds in legumes and their germinated products," J. Agric. Food Chem., vol. 54, no. 11, pp. 3807-3814, 2006.

24. L. X. López-Martínez, N. Leyva-López, E. P. Gutiérrez-Grijalva, and J. B. Heredia, "Effect of cooking and germination on bioactive compounds in pulses and their health benefits," J. Funct. Foods, vol. 38, pp. 624-634, 2017.
25. R. A. Habiba, "Changes in anti-nutrients, protein solubility, digestibility, and $\mathrm{HCl}$-extractability of ash and phosphorus in vegetable peas as affected by cooking methods," Food Chem., vol. 77, no. 2, pp. 187-192, 2002.

26. X. Guo, T. Li, K. Tang, and R. H. Liu, "Effect of germination on phytochemical profiles and antioxidant activity of mung bean sprouts (Vigna radiata)," J. Agric. Food Chem., vol. 60, no. 44, pp. 11050-11055, 2012.

27. F. Manan, T. Hussain, I. Alli, and P. Iqbal, "Effect of cooking on phytic acid content and nutritive value of Pakistani peas and lentils," Food Chem., vol. 23, no. 2, pp. 81-87, 1987.

28. E. A. Shimelis and S. K. Rakshit, "Effect of processing on antinutrients and in vitro protein digestibility of kidney bean (Phaseolus vulgaris L.) varieties grown in East Africa," Food Chem., vol. 103, no. 1, pp. 161-172, 2007.

29. E. Doria, B. Campion, F. Sparvoli, A. Tava, and E. Nielsen, "Anti-nutrient components and metabolites with health implications in seeds of 10 common bean (Phaseolus vulgaris L. and Phaseolus lunatus L.) landraces cultivated in southern Italy," J. Food Compos. Anal., vol. 26, no. 1-2, pp. 72-80, 2012.

30. A. K. Ramírez-Jiménez, R. Reynoso-Camacho, M. E. Tejero, F. LeónGalván, and G. Loarca-Piña, "Potential role of bioactive compounds of Phaseolus vulgaris L. on lipid-lowering mechanisms," Food Res. Int., vol. 76, no. P1, pp. 92-104, 2015.

31. K. MuraMoto, "Lectins as bioactive proteins in foods and feeds," Food Sci. Technol. Res., vol. 23, no. 4, pp. 487-494, 2017. 